\title{
EFEKTIVITAS PROGRAM KAMPUNG KELUARGA BERENCANA (KB) DAN DAMPAKNYA TERHADAP KESEJAHTERAAN KELUARGA MISKIN DI KOTA DENPASAR
}

\author{
Ni Luh Novi Restiyani ${ }^{1}$ \\ I Gusti Wayan Murjana Yasa ${ }^{2}$ \\ ${ }^{1,2}$ Fakultas Ekonomi dan Bisnis Universitas Udayana (Unud), Bali, Indonesia \\ E-mail: nrestyani@yahoo.co.id
}

\begin{abstract}
ABSTRAK
Tujuan dari penelitian ini untuk mengetahui dan menganalisis pengaruh pendidikan istri dan peran petugas KB terhadap efektivitas program Kampung KB dan kesejahteraan keluarga miskin di Kota Denpasar. Pengambilan sampel dalam penelitian ini dilakukan secara Accidental Sampling dengan jumlah sampel sebanyak 81 keluarga miskin. Data dikumpulkan dengan metode observasi dan wawancara terstruktur yang selanjutnya dianalisis dengan teknik analisis jalur. Hasil penelitian menunjukkan bahwa pelaksanaan program Kampung KB di Kota Denpasar belum efektif. Pendidikan istri dan peran petugas $\mathrm{KB}$ berpengaruh positif dan signifikan terhadap efektivitas program Kampung KB. Hal ini menunjukan semakin tinggi pendidikan istri dan semakin aktif petugas KB maka pelaksanaan program Kampung KB akan semakin efektif. Pendidikan istri berpengaruh positif dan signifikan, sementara peran petugas $\mathrm{KB}$ berpengaruh positif dan tidak signifikan terhadap kesejahteraan keluarga miskin. Efektivitas program Kampung KB berpengaruh positif dan signifikan terhadap kesejahteraan keluarga miskin di Kota Denpasar. Hasil penelitian juga menunjukkan bahwa pendidikan istri dan peran petugas $\mathrm{KB}$ berpengaruh tidak langsung terhadap kesejahteraan keluarga miskin di Kota Denpasar.
\end{abstract}

Kata Kunci: pendidikan, peran petugas, keluarga berencana, efektivitas, kesejahteraan keluarga

\begin{abstract}
The purpose of this study was to determine and analyze the influence of wife education and the role of family planning officers on the effectiveness of the KB Village program and the welfare of poor families in Denpasar City. Sampling in this study was conducted accidentally sampling with a total sample of 81 poor families. Data was collected by observation and structured interviews which were then analyzed by path analysis techniques. The results of the study showed that the implementation of the KB Village program in Denpasar City was not yet effective. Wife education and the role of family planning officers have a positive and significant effect on the effectiveness of the KB Village program. This shows that the higher the wife's education and the more active the family planning officer, the more effective the $K B$ Village program will be. Wife education has a positive and significant effect, while the role of family planning officers has a positive and not significant effect on the welfare of poor families. The effectiveness of the KB Village program has a positive and significant effect on the welfare of poor families in Denpasar City. The results also showed that wife education and the role of family planning officers indirectly affected the welfare of poor families in Denpasar City.
\end{abstract}

Keywords: education, officer role, family planning, effectiveness, family welfare 


\section{PENDAHULUAN}

Indonesia merupakan salah satu negara dengan jumlah penduduk terbesar di dunia. Menurut Perserikatan Bangsa - Bangsa (PBB) (2018), jumlah penduduk Indonesia hingga akhir tahun 2018 adalah sekitar 266,79 juta jiwa dan menempati urutan ke empat negara dengan jumlah penduduk terbanyak di dunia. Besarnya jumlah penduduk merupakan dampak dari pesatnya laju pertumbuhan penduduk. Pertumbuhan penduduk yang cepat tersebut kemudian memberikan dampak negatif terhadap penduduk miskin terutama yang paling miskin (Margareni, 2016). Ada beberapa hal yang menjadikan penduduk berpengaruh negatif terhadap tingkat kemiskinan. Jumlah penduduk yang besar menjadi sumber permintaan akan berbagai macam barang dan jasa yang kemudian akan menggerakkan berbagai macam kegiatan ekonomi sehingga menguntungkan semua pihak, menurunkan biaya produksi dan menciptakan sumber pasokan atau penawaran tenaga kerja murah dalam jumlah yang memadai sehingga akan merangsang output atau produksi agregat yang lebih tinggi lagi. Kesejahteraan masyarakat akan meningkat, yang berarti tingkat kemiskinan akan turun (Todaro, 2000).

Salah satu hal yang menjadi penyebab tingginya angka kemiskinan di Indonesia saat ini adalah aspek demografi (kependudukan). Aspek demografi tersebut diataranya meliputi tingginya laju pertumbuhan penduduk dan rendahnya kualitas sumber daya manusia. Pertumbuhan penduduk merupakan variabel penting dalam pembangunan karena untuk mencapai tujuan akhir dari peningkatan kualitas hidup generasi sekarang dan mendatang (Suandi et al., 
2014). Pertumbuhan penduduk yang tidak terkendali pada akhirnya akan menyebabkan meningkatnya angka kemiskinan apabila tidak diiringi dengan peningkatan kualitas sumber daya manusia. Malthus berpendapat bahwa peningkatan jumlah penduduk yang tidak terkendali akan menyebabkan tergerusnya sumber daya alam karena pada umumnya pertumbuhan penduduk terjadi menurut deret ukur sedangkan alat pemuas kebutuhan meningkat menurut deret hitung. Pada akhirnya hal ini mendatangkan berbagai permasalahan seperti kelaparan, muncul wabah penyakit dan lain-lain. Hal inilah yang kemudian dikenal dengan "the law of diminishing return".

Kemiskinan hingga saat ini masih merupakan masalah yang dihadapi setiap negara di dunia, tidak hanya negara terbelakang namun juga negara maju. Berdasarkan penelitian yang dilakukan Fan dkk. (2005) di China dan India pertumbuhan ekonomi yang tidak merata di daerah perkotaan dan di daerah pedesaan adalah penyebab tingginya tingkat kemiskinan di kedua negara tersebut. Pertumbuhan pertanian menyebabkan penurunan angka kemiskinan baik di daerah pedesaan maupun di daerah perkotaan, namun penurunan kemiskinan akibat pertumbuhan pertanian lebih signifikan terjadi di daerah pedesaan daripada daerah perkotaan. Hal ini sejalan dengan penelitian Bidani dan Martin (2006) yang mengatakan bahwa kemiskinan di daerah pedesaan di Indonesia lebih parah dan dalam dibandingkan dengan kemiskinan di daerah perkotaan bila dihitung menggunakan garis kemiskinan. Menurut McCulloch (2008), kemiskinan di Indonesia sebagian besar dialami oleh petani (sektor pertanian). Salah satu kebijakan yang diambil pemerintah dalam upaya mengentaskan kemiskinan di 
sektor pertanian ini adalah dengan meningkatkan harga beras dengan harapan mampu meningkatkan kesejahteraan petani dan mengurangi kemiskinan di sektor pertanian, namun kebijakan yang diterapkan belum efektif karena pada dasarnya jumlah hasil pertanian jauh lebih kecil daripada jumlah konsumen hasil pertanian itu sendiri.

Kemiskinan telah menjadi masalah yang kompleks dan kronis baik pada tingkat nasional maupun regional, sehingga diperlukan strategi yang tepat dan berkelanjutan untuk menanggulanginya. Menurut Badan Pusat Statistik, kemiskinan adalah ketidakmampuan memenuhi standar minimum kebutuhan dasar yang meliputi kebutuhan makan maupun non makan (Budhi, 2013). Kemiskinan dapat menjadi indikasi bahwa tingkat kesejahteraan masyarakat Indonesia masih tergolong rendah. Namun, tidak semua kemiskinan identik dengan ketidaksejahteraan, demikian juga dengan tingkat pendapatan yang tinggi belum tentu mencerminkan tingkat kesejahteraan yang tinggi pula (Subagio $d k k$, 2001). Menurut Soesilowati dalam Hukom (2014), kesejahteraan masyarakat adalah kondisi terpenuhinya kebutuhan dasar yang tercermin dari rumah yang layak, tercukupinya kebutuhan sandang dan pangan, biaya pendidikan dan kesehatan yang murah dan berkualitas atau kondisi dimana setiap individu mampu memaksimalkan utilitasnya pada tingkat batas anggaran tertentu dan kondisi dimana tercukupinya kebutuhan jasmani dan rohani.

Kesejahteraan menurut Badan Pusat Statistik (2007) adalah suatu kondisi dimana seluruh kebutuhan jasmani dan rohani dari rumah tangga tersebut dapat dipenuhi sesuai dengan tingkat hidup. Konsep kesejahteraan selama ini selalu 
dikaitkan dengan pendapatan, namun pada dasarnya kesejahteraan tidak hanya menyangkut aspek ekonomi namun juga mencakup aspek lainnya dalam kehidupan seperti pendidikan, kesehatan dan aktivitas sosial. Menurut Keyes (2002), kontak sosial yang berkualitas dapat meningkatkan kesejahteraan masyarakat, kegiatan sosial dengan kelompok-kelompok berkorelasi kuat dengan kesejahteraan. Menurut Sunariani (2014), modal sosial juga mempengaruhi kesejahteraan masyarakat.

Program pembangunan yang dilaksanakan pemerintah Indonesia selama ini telah memberikan perhatian besar terhadap upaya pengentasan kemiskinan. Meskipun demikian, masalah kemiskinan sampai saat ini masih menjadi masalah yang belum terselesaikan. Penelitian Yusuf dan Andy (2015), sejak September 2014 hingga Maret 2015 populasi penduduk miskin di Indonesia meningkat meskipun pertumbuhan ekonomi mendekati lima persen. Hal ini merupakan efek dari pertumbuhan yang melambat, meningkatnya harga pangan, jatuhnya upah riil petani dan penundaan pembayaran kompensasi harga bahan bakar minyak. Berdasarkan data Badan Pusat Statistik (2018) jumlah penduduk Indonesia sejak tahun 2015 hingga tahun 2018 terus mengalami penurunan namun masih pada kisaran diatas 25 juta jiwa. Pada tahun 2015 jumlah penduduk miskin di Indonesia mencapai 28.592.800 jiwa atau sebesar 11,22 persen yang terus menurun hingga pada tahun 2018 menjadi 25.949.800 jiwa atau 9,82 persen.

Provinsi Bali merupakan salah satu provinsi dengan tingkat kemiskinan terendah di Indonesia. Hal itu dapat diketahui dari data publikasi BPS yang menunjukkan bahwa persentase penduduk miskin di Provinsi Bali merupakan 
yang terendah setelah Provinsi DKI Jakarta. Demikian pula tingkat kesejahteraan masyarakat Provinsi Bali yang meningkat setiap tahunnya, namun peningkatan cenderung rendah dan masih terjadinya disparitas pendapatan antardaerah (Yasa dan Sudarsana, 2015). Persentase serta jumlah penduduk Provinsi Bali dapat dilihat dalam Tabel 1.

Tabel 1.

Jumlah dan Persentase Penduduk Miskin di Provinsi Bali Tahun 2014 - 2017

\begin{tabular}{|c|c|c|c|c|c|c|c|c|c|}
\hline \multirow[t]{2}{*}{ No } & \multirow[t]{2}{*}{ Kabupaten/Kota } & \multicolumn{4}{|c|}{$\begin{array}{l}\text { Jumlah Penduduk Miskin Provinsi } \\
\text { Bali Menurut Kabupaten/Kota } \\
\text { (Ribu Jiwa) }\end{array}$} & \multicolumn{4}{|c|}{$\begin{array}{l}\text { Persentase Penduduk Miskin } \\
\text { Provinsi Bali Menurut } \\
\text { Kabupaten/Kota }(\%)\end{array}$} \\
\hline & & 2014 & 2015 & 2016 & 2017 & 2014 & 2015 & 2016 & 2017 \\
\hline 1 & Jembrana & 15.8 & 15.83 & 14.53 & 14.78 & 5.83 & 5.84 & 5.33 & 5.38 \\
\hline 2 & Tabanan & 24.4 & 24.05 & 21.9 & 21.66 & 5.61 & 5.52 & 5 & 4.92 \\
\hline 3 & Badung & 15.4 & 14.4 & 12.91 & 13.16 & 2.54 & 2.33 & 2.06 & 2.06 \\
\hline 4 & Gianyar & 22.5 & 22.89 & 22.13 & 22.42 & 4.57 & 4.61 & 4.44 & 4.46 \\
\hline 5 & Klungkung & 12.3 & 12.11 & 11.21 & 11.15 & 7.01 & 6.91 & 6.35 & 6.29 \\
\hline 6 & Bangli & 13 & 12.74 & 11.66 & 11.76 & 5.86 & 5.73 & 5.22 & 5.23 \\
\hline 7 & Karangasem & 29.7 & 30.33 & 27.12 & 27.02 & 7.3 & 7.44 & 6.61 & 6.55 \\
\hline 8 & Buleleng & 43.7 & 43.43 & 37.55 & 37.48 & 6.79 & 6.74 & 5.79 & 5.74 \\
\hline \multirow[t]{2}{*}{9} & Denpasar & 19.2 & 20.94 & 19.17 & 20.7 & 2.21 & 2.39 & 2.15 & 2.27 \\
\hline & Provinsi Bali & 196 & 196.71 & 178.18 & 180.13 & 4.76 & 4.74 & 4.25 & 4.25 \\
\hline
\end{tabular}

Sumber: Data diolah, 2019

Berdasarkan Tabel 1 jumlah penduduk miskin di Provinsi Bali pada tahun 2014 hingga 2017 mengalami fluktuasi. Jumlah penduduk miskin sempat menurun pada tahun 2016 namun kembali meningkat pada tahun 2017. Namun bila dilihat lebih jauh persentase penduduk miskin di Bali pada tahun 2015 mengalami penurunan sedangkan pada tahun 2017 tetap pada besaran 4,25 persen. Dari Tabel 1 juga dapat diketahui bahwa meskipun pada tahun 2015 persentase penduduk miskin menurun namun tingkat penurunannya masih tergolong rendah yakni sebesar 0,02 persen dari tahun 2014. Melalui tabel tersebut juga dapat dilhat persentase penduduk miskin pada tahun 2016 dan 2017 masih berada pada besaran 4,25 persen, namun bila diperhatikan lebih jauh dengan persentase yang 
tetap jumlah penduduk miskin pada tahun 2017 justru lebih banyak dari tahun 2016.

Pentingnya meningkatkan kesejahteraan masyarakat perlu dilakukan mengingat meningkatnya kesejahteraan merupakan tujuan akhir pelaksanaan pembangunan ekonomi (Maipita, 2014). Selain itu kesejahteraan juga merupakan salah satu tolak ukur keberhasilan pembangunan. Maka dari itu menjaga dan meningkatkan kesejahteraan masyarakat merupakan tanggung jawab pemerintah setiap negara. Kesejahteraan masyarakat juga merupakan salah satu bagian dari tujuan terbentuknya Negara Indonesia sebagaimana yang tercantum dalam alinea IV Pembukaan Undang - Undang Dasar 1945. Salah satu bentuk kebijakan yang diambil pemerintah Indonesia untuk menekan laju pertumbuhan penduduk yang menjadi salah satu faktor pendorong kemiskinan adalah dengan menerapkan program Keluarga Berencana (KB) pada masyarakat. Penerapan KB dalam masyarakat diharapkan mampu meningkatkan kesejahteraan keluarga melalui pengaturan jumlah anak sehingga seluruh kebutuhan keluarga dapat terpenuhi. Pelaksanaan program KB yang dimulai pada tahun 1970-an bertujuan untuk mengendalikan pertumbuhan jumlah penduduk. Upaya pemerintah untuk menyukseskan program $\mathrm{KB}$ dengan mengalokasikan anggaran yang terus meningkat setiap tahun melalui Anggaran Pendapatan dan Belanja Negara (APBN) pada tingkat nasional dan melalui Anggaran Pendapatan dan Belanja Daerah pada tingkat daerah (Uppun, 2016). Namun beberapa dekade terakhir program KB mulai meredup dan tidak terdengar gaungnya. 
Untuk menghidupkan kembali program KB pemerintah menerapkan inovasi baru, yang dikenal dengan Kampung KB. Kampung KB merupakan bentuk reorientasi kebijakan pemerintah yang tidak hanya terfokus pada penekanan laju pertumbuhan penduduk namun juga pada peningkatan kualitas penduduk dan kesejahteraan keluarga. Peningkatan kesejahteraan keluarga perlu diperhatikan sebab keluarga merupakan satuan terkecil dalam kehidupan bermasyarakat sehingga keluarga memiliki peran dan nilai strategis dalam menunjang keberhasilan pembangunan. Keluarga juga merupakan wahana pertama dan utama dalam membentuk sumberdaya manusia yang berkualitas. Program Kampung KB mulai dijalankan Pemerintah Republik Indonesia pada tahun 2016.

Kampung KB dirancang sebagai upaya mengaktualisasikan dan mengaplikasikan delapan fungsi keluarga yang meliputi : fungsi keagamaan, fungsi sosial budaya, fungsi cinta kasih, fungsi perlindungan, fungsi reproduksi, fungsi sosial dan pendidikan, fungsi ekonomi serta fungsi lingkungan. Delapan fungsi keluarga tersebut merupakan cerminan dari kesejahteraan dan ketahanan keluarga. Pemberdayaan keluarga di bidang ekonomi merupakan salah satu usaha yang dapat dilakukan untuk meningkatkan potensi keluarga dalam hal kesejahteraan (Heryendi dan Marhaeni, 2013). Program Kampung KB juga diharapkan dapat menjadi replikasi bagi desa-desa lain di sekitarnya dalam memberdayakan masyarakat agar dapat meningkatkan kesejahteran keluarga masyarakatnya. Apabila hal tersebut dapat terwujud maka pelaksanaan pembangunan di Indonesia akan lebih merata hingga ke daerah pedesaan dan pelosok. 
Beberapa hal yang melatarbelakangi terbentuknya program ini, diantaranya: (1) Program KB tidak lagi bergema dan terdengar gaungnya seperti pada era Orde Baru; (2) untuk meningkatkan kualitas hidup masyarakat di tingkat kampung atau yang setara melalui program KKBPK serta pembangunan sector terkait dalam rangka mewujudkan keluarga kecil berkualitas; (3) penguatan program KKBPK yang dikelola dan diselenggarakan dari, oleh dan untuk masyarakat; (4) mewujudkan cita-cita pembangunan Indonesia yang tertuang dalam Nawacita terutama agenda prioritas ke 3 yaitu "Memulai pembangunan dari pinggiran dengan memperkuat daerah-daerah dan desa dalam kerangka negara kesatuan" serta Agenda Prioritas ke 5, yaitu "Meningkatkan kualitas hidup masyarakat Indonesia"; (5) mengangkat dan menggairahkan kembali program KB guna menyongsong tercapainya bonus demografi yang diprediksi akan terjadi pada tahun 2010 - 2030. Program Kampung KB merupakan program pemerintah dalam memperkuat program Kependudukan Keluarga Berencana dan Pembangunan Keluarga (KKBPK) dengan mempersempit ruang lingkup sasaran yaitu dalam tingkat wilayah/desa/kelurahan.

Pembentukan Kampung KB ini bertujuan untuk meningkatkan kualitas hidup masyarakat ditingkat kampung atau setara, melalui program Kependudukan, Keluarga Berencana dan Pembangunan Keluarga (KKBPK) serta membangun sektor terkait dalam rangka mewujudkan keluarga kecil berkualitas. Menurut penelitian Arinta (2018), pelaksanaan program Kampung KB memberikan perubahan nyata pada kehidupan sosial masyarakat Kelurahan Harjosari II Medan, Sumatra Utara. Hal ini dicerminkan dari meningkatnya kualitas kesehatan 
masyarakat terutama pada keluarga dengan balita, adanya perbaikan kualitas lingkungan serta perubahan pada aspek ekonomi. Sementara itu Peneliti Madya Perwakilan BKKBN Jawa Timur, Mardiyono (2017) dalam penelitiannya mengenai "Pemberdayaan Keluarga Melalui Kampung KB dalam Upaya Peningkatan Program KKBPK dan Terkait di Jawa Timur" menyatakan bahwa pelaksanaan Kampung KB berdampak pada peningkatan peserta aktif pengguna KB. Dari aspek ekonomi, pelaksanaan program lintas sektoral juga dilakukan pelatihan - pelatihan untuk meningkatkan pendapatan keluarga.

Zuhriyah dkk (2017) mengevaluasi pelaksanaan Kampung KB menyatakan bahwa Kampung KB belum efektif dalam peningkatan program Keluarga Berencana. Hal ini ditinjau dari 3 (tiga) aspek, yakni : (1) input yang meliputi jumlah tenaga kerja dan ketersediaan anggaran; (2) proses yang meliputi evaluasi seleksi lokasi, sosialisasi, pengkajian potensi wilayah dan lain-lain; (3) output, sesuai dengan yang tertera dalam petunjuk teknis Kampung KB oleh BKKBN. Bertolak dari penelitian di atasdapat diketahui bahwa Kampung KB masih belum mampu meningkatkan efektivitas program KB. Hal tersebut tercermin dari belum efektifnya ketiga aspek yang dijadikan indikator pengujian.

Dalam pelaksanaannya, BKKBN yang merupakan lembaga pemerintah yang bertanggung jawab atas pelaksanan program ini juga turut menggandeng lembaga pemerintahan lain yang berkaitan dengan penerapan delapan fungsi keluarga. Berdasarkan data $\mathrm{BKKBN}$, hingga akhir tahun 2018 terbentuk \pm 12.454 unit Kampung KB yang tersebar di seluruh wilayah di Indonesia. Di Provinsi Bali 
jumlah Kampung KB yang telah terbentuk adalah sebanyak 121 unit sebagaimana tercantum pada Tabel 2.

Berdasarkan data Tabel 2 dapat diketahui bahwa jumlah kampung KB terbanyak di Provinsi Bali berada di Kabupaten Buleleng yakni sebanyak 36 unit. Kota Denpasar yang merupakan ibukota Provinsi Bali memiliki 4 Kampung KB. Kampung KB di Kota Denpasar tersebar di empat kecamatan, dengan masing masing kecamatan memiliki satu Kampung KB. Sebaran Kampung KB di Kota Denpasar yakni : (1) Desa Pemogan untuk Kecamatan Denpasar Selatan; (2) Desa Sumerta Kaja untuk Kecamatan Denpasar Timur; (3) Desa Dauh Puri Kangin untuk Denpasar Utara; dan (4) Dauh Puri Kauh untuk Denpasar Barat. Keempat desa tersebut dipilih karena memenuhi kriteria pembentukan Kampung KB yakni jumlah Pra-KS (keluarga sangat miskin) dan KS-I (keluarga miskin) lebih besar daripada jumlah Pra-KS dan KS-I di tingkat kecamatan serta jumlah peserta KB dibawah capaian peserta KB di tingkat kecamatan. Dengan terbentuknya kampung KB di masing - masing kecamatan diharapkan kesejahteraan masyarakat dapat meningkat yang kemudian akan berdampak pada menurunnya tingkat kemiskinan.

Tabel 2.

Persebaran Kampung KB di Provinsi Bali Tahun 2018

\begin{tabular}{clc}
\hline No & \multicolumn{1}{c}{ Kabupaten/Kota } & Jumlah Kampung KB (unit) \\
\hline 1 & Jembrana & 10 \\
2 & Tabanan & 10 \\
3 & Badung & 12 \\
4 & Gianyar & 16 \\
5 & Klungkung & 5 \\
6 & Bangli & 17 \\
7 & Karangasem & 11 \\
8 & Buleleng & 36 \\
9 & Denpasar & 4 \\
& Provinsi Bali & $\mathbf{1 2 1}$ \\
\hline
\end{tabular}


Keberhasilan program Kampung $\mathrm{KB}$ tidak terlepas dari peran para pemangku kepentingan yang terlibat di dalamnya. Salah satu pihak yang memiliki peran penting dalam pelaksanaan program ini adalah petugas $\mathrm{KB}$ yang terdiri atas Penyuluh KB dan Petugas Lapangan Keluarga Berencana (PLKB). PLKB merupakan petugas yang bertugas melaksanakan kegiatan penyuluhan, pelayanan, evaluasi, dan pengembangan Keluarga Berencana Nasional. PKB dan PLKB merupakan ujung tombak pengelola $\mathrm{KB}$ di lini lapangan yang tidak hanya bertugas dalam menggerakkan masyarakat agar ikut berpartisipasi dalam program KB nasional. Namun pada saat bersamaan juga membangun kemitraan dengan berbagai pihak dalam upaya meningkatkan kualitas hidup dan kesejahteraan masyarakat. Menurut Kurniawan (2010), Penyuluh Keluarga Berencana (PKB) berupaya menekan angka kelahiran penduduk dan pada saat bersamaan berusaha meningkatkan kualitas kesejahteraan hidup penduduk.

Di samping petugas $\mathrm{KB}$, pendidikan istri juga mempengaruhi keberhasilan pelaksanaan program Kampung $\mathrm{KB}$ maupun kesejahteraan keluarga secara langsung. Pendidikan pada hakekatnya adalah upaya sadar yang dilakukan oleh seseorang atau sekelompok orang (penduduk) untuk meningkatkan kemampuan (Seran, 2017). Keluarga dengan istri berpendidikan lebih tinggi berpotensi untuk lebih sejahtera dibandingkan keluarga dengan istri berpendidikan rendah (Riza dkk., 2014). Istri dengan pendidikan lebih tinggi, dengan wawasan dan ketrampilan yang dimiliki mampu mengelola sumber daya keluarga yang ada secara lebih baik untuk memenuhi kebutuhan keluarga, sehingga kesejahteraan keluarga meningkat. Menurut Hidayat (2004), tingkat pendidikan mempengaruhi 
penerimaan seseorang terhadap sesuatu hal yang baru. Semakin tinggi tingkat pendidikan seseorang maka semakin mudah baginya untuk menerima hal-hal yang baru yang ada di sekitarnya serta semakin bagus pula pengetahuan yang dimiliki. Dalam konteks pelaksanaan program Kampung KB, pendidikan istri berkaitan dengan partisipasi istri dalam mengikuti setiap kegiatan yang dilaksanakan dalam rangka menyukseskan program tersebut. Semakin tinggi tingkat pendidikan istri maka semakin luas pola pikir serta wawasan dan pengetahuan istri dalam mengikuti setiap kegiatan terkait, sehingga dapat menunjang keberhasilan pelaksanaan program Kampung KB.

Efektivitas program Kampung KB dalam meningkatkan kesejahteraan keluarga dipengaruhi oleh beberapa faktor, diantaranya : pendidikan istri dan peran PLKB. Pendidikan merupakan salah satu aspek penting yang mempengaruhi segala bidang kehidupan manusia. Saat ini pendidikan bukan hanya merupakan suatu proses pembelajaran dalam masyarakat, tetapi sudah berkembang menjadi pusat dari segala pengetahuan (Pertiwi dan Akif, 2016). Pendidikan mempunyai fungsi utama yang selalu ada dalam perkembangan sejarah manusia yaitu untuk meningkatkan taraf pengetahuan manusia. Pendidikan merupakan sarana sosialisasi nilai- nilai budaya yang ada di masyarakat setempat, juga sebagai media untuk menstransmisikan nilai- nilai baru maupun mempertahankan nilai- nilai lama.

Menurut Siti Walidah dalam Ardiyani (2017) perempuan dalam suatu keluarga bukan hanya sebagai pelengkap bagi kaum laki-laki, melainkan merupakan penggerak kemajuan keluarga, bangsa dan negara. Untuk itu 
pendidikan perempuan juga dapat mempengaruhi kesejahteraan keluarga. Dalam hal ini pendidikan perempuan (istri) juga menjadi salah satu faktor penting yang memengaruhi efektivitas program Kampung $\mathrm{KB}$ dalam meningkatkan kesejahteraan keluarga. Semakin tinggi tingkat pendidikan perempuan (istri) maka semakin luas pula pengetahuan dan wawasannya dalam menyerap berbagai informasi terkait pelaksanaan program dan hal inilah yang akan mempengaruhi efektivitas pelaksanaan program tersebut. Menurut Sastropoetro (1988 : 22) keikutsertaan seseorang dalam suatu kegiatan tertentu akan sangat dipengaruhi oleh tingkat pendidikannya. Hal ini disebabkan karena pendidikan memberikan pengetahuan-pengetahuan baru yang didasarkan pada pemikiran rasional, sehingga hal ini akan mengubah sikap seseorang. Jadi pendidikan itu sndiri merupakan proses pembinaan pengetahuan sikap dan perbuatan manusia dalam rangka mempengaruhi dan mengubah pergetahuannya sesuai dengan tujuannya. Dengan demikian maka paitisipasi seseorang dalam suatu kegiatan berhubungan dengan tingkat pengetahuan yang dimilikinya. Bila dikaitkan langsung dengan kesejahteraan keluarga, pendidikan istri juga memiliki peran yang sangat penting, semakin tinggi pendidikan istri maka kesempatan untuk bekerja dan turut menyumbangkan pendapatan untuk pemenuhan kebutuhan keluarga pun semakin tinggi, hal inilah yang kemudian akan memengaruhi kesejahteraan keluarga secara langsung (Puspitawati, 2012).

Keberhasilan pelaksanaan Kampung KB tidak terlepas dari peran PKB dan PLKB yang merupakan ujung tombak lini lapangan dalam menjabarkan visi dan misi program kependudukan, keluarga berencana dan pembangunan keluarga 
yang harus diterjemahkan dengan baik di lapangan sehingga masyarakat sebagai pihak penerima dan pengguna program dapat menikmatinya (Afniyanty, 2016). Tugas utama dari PKB adalah mempertahankan pencapaian angka kesertaan KB yang tinggi dan mengendalikan angka kelahiran penduduk di wilayah binaannya. Peran PKB dan PLKB memotivasi, membina dan meningkatkan akseptor KB; menjaga hubungan komunikasi dengan keluarga binaan serta menentukan angka kesertaan KB yang tinggi berdampak pada penurunan angka kelahiran. Sebagai tombak pelaksanaan kegiatan di lapangan, PKB dan PLKB langsung berhadapan dengan calon akseptor $\mathrm{KB}$ terkait berbagai permasalahan dan isu di masyarakat. Keberhasilan program KKBPK tergantung kepandaian petugas KB meyakinkan calon akseptor $\mathrm{KB}$ untuk ikut serta dalam program kependudukan keluarga berencana dan pembangunan keluarga melalui advokasi, komunikasi, informasi dan edukasi atau yang biasa disebut konseling. Menurut penelitian yang dilakukan Yusuf (2018), PLKB juga dapat dikatakan berperan dalam meningkatkan kesejahteraan keluarga khususnya di Kabupaten Donggala. Melalui program KB yang dikembangkan di Kabupaten Donggala ditengah keterbatasan pendapatan masyarakat, kelancaran program $\mathrm{KB}$ mampu mengendalikan jumlah anggota keluarga yang kemudian mampu menekan biaya/pengeluaran keluarga. Hal tersebut diketahui dari sebagian besar responden yang menyatakan bahwa PLKB berperan dalam meningkatkan kesejahteraan keluarga.

Bertolak dari latar belakang di atas, dapat dikemukakan masalah penelitian sebagai berikut. 1. Apakah pelaksanaan program Kampung KB di Kota Denpasar telah efektif? 2. Bagaimanakah pengaruh pendidikan istri dan peran petugas $\mathrm{KB}$ 
terhadap efektivitas program Kampung KB di Kota Denpasar? 3. Bagaimanakah pengaruh pendidikan istri, peran petugas $\mathrm{KB}$ dan efektivitas program Kampung KB terhadap kesejahteraan keluarga miskin di Kota Denpasar? 4. Apakah efektivitas program Kampung KB memediasi pengaruh pendidikan istri dan peran petugas KB terhadap kesejahteraan keluarga miskin di Kota Denpasar?

\section{METODE PENELITIAN}

Lokasi yang dipilih untuk melakukan penelitian ini adalah Kota Denpasar. Kota Denpasar dipilih sebagai lokasi penelitian karena penelitian ini merupakan kajian awal (baru). Kampung $\mathrm{KB}$ di Kota Denpasar juga aktif dalam melaksanakan segala kegiatan yang berkaitan dengan pelaksanaan program Kampung $\mathrm{KB}$ sehingga cukup representatif untuk menggambarkan pengaruh pelaksanaan program terhadap kesejahteraan keluarga.

Populasi penelitian ini mencakupsebanyak 423 keluarga miskin di empat desa yang melaksanakan program Kampung KB di Kota Denpasar. Berdasarkan jumlah tersebut, jumlah sampel dapat dihitung menggunakan rumus Slovin dengan batas kesalahan 10 persen, sehingga diperoleh sampel sebanyak $81 \mathrm{KK}$ miskin di Kota Denpasar. Metode penentuan sampel yang digunakan dalam penelitian ini adalah Non Probability Sampling dengan menggunakan metode Accidental Sampling, yang merupakan pengambilan sampel secara aksidental/kebetulan.

Penelitian ini menggunakan alat analisis faktor konfirmatori yang terdiri atas Kaiser Meyer Olkin (KMO) atau Barlett's test dan Measures of Sampling 
Adequancy (MSA). Uji KMO dan MSA dilakukan untuk menguji kebenaran indikator variabel serta untuk mengonfirmasi kesesuaian model pengukuran dengan hipotesis. Nilai KMO minimal 0,5. Nilai KMO dibawah 0,5 menunjukkan bahwa analisis faktor tidak dapat digunakan. Measures of Sampling Adequancy (MSA) pada analisis faktor akan menunjukkan kelayakan model yang digunakan dalam analisis faktor. Nilai MSA minimal 0,5. Apabila nilai MSA dibawah 0,5 maka model yang digunakan tidak layak dipakai dalam analisis factor.

Untuk mengetahui tingkat efektivitas program Kampung KB dalam meningkatkan kesejahteraan keluarga di Kota Denpasar pada penelitian digunakan rumus efektivitas sebagai berikut.

Efektivitas $=\frac{\text { Realisasi }}{\text { Target }} \times 100 \%$

Keterangan :

Realisasi : pencapaian pelaksanaan program Kampung KB.

Target : tujuan yang hendak dicapai.

Untuk menaksir hubungan kausalitas antarvariabel pada penelitian ini digunakan analisis jalur. Analisis jalur merupakan perluasan dari analisis regresi linier berganda yang digunakan untuk mengetahui hubungan langsung variabel independen terhadap variabel dependen dan hubungan tidak langsung yang melalui variabel mediasi. Maka dapat dibuat persamaan sebagai berikut.

$\mathrm{Y}_{1}={ }^{\beta_{1}} \mathrm{X}_{1}+{ }^{\beta_{2}} \mathrm{X}_{2}++\mathrm{e}_{1}$

$\mathrm{Y}_{2}=\beta_{3} \mathrm{X}_{1}+{ }^{\beta_{4}} \mathrm{X}_{2}++{ }_{5} \mathrm{Y}_{1}+\mathrm{e}_{2}$

Keterangan :

$\mathrm{Y}_{2}=$ Kesejahteraan Keluarga

$\mathrm{Y}_{1} \quad=$ Efektivitas program Kampung $\mathrm{KB}$

$\mathrm{X}_{1} \quad=$ Pendidikan Istri 
$\mathrm{X}_{2}=$ Peran petugas $\mathrm{KB}$

$\beta_{1} \ldots \beta_{5}=$ Koefisien regresi masing - masing variabel $\mathrm{X}$

$\mathrm{e}_{1}, \mathrm{e}_{2}=$ error term

\section{HASIL DAN PEMBAHASAN}

Kaiser Meyer Olkin (KMO) digunakan untuk mengetahui validitas konstruk dari analisis faktor. Analisis faktor dianggap layak jika besaran KMO diatas 0,5. Hasil uji KMO penelitian ini dapat dilihat pada Tabel 3.

Tabel 3.

Hasil Uji KMO Variabel Penelitian

\begin{tabular}{clll}
\hline No & \multicolumn{1}{c}{ Faktor } & KMO & Sig. Chi-square \\
\hline 1 & Peran Petugas KB (X2) & 0,566 & 0,000 \\
2 & Efektivitas Program Kampung KB (Y1) & 0,630 & 0,000 \\
3 & Kesejahteraan Keluarga (Y2) & 0,629 & 0,000 \\
\hline Sumber: Data diolah, 2019
\end{tabular}

Hasil uji KMO berdasarkan Tabel 3 menunjukkan bahwa nilai Kaiser Meyer Olkin (KMO) untuk ketiga variabel adalah diatas 0,5 dengan signifikansi kurang dari 0,05. Hasil tersebut berarti masing - masing variabel memiliki kecukupan sampel untuk melakukan analisis faktor.

Tabel 4 menunjukkan hasil uji MSA dari masing - masing variabel. Variabel Peran Petugas KB terbentuk atas empat indikator yang meliputi keaktifan Petugas KB dalam menjalankan tugasnya di masyarakat. Berdasarkan tabel tersebut dapat dilihat bahwa masing - masing indikator dari variabel peran Petugas KB memiliki nilai MSA diatas 0,5 yang berarti masing - masing model layak digunakan untuk melanjutkan analisis penelitian.

Hal yang sama juga dapat dilihat untuk variabel efektivitas program Kampung KB dan kesejahteraan keluarga. Kedua variabel tersebut terbentuk atas enam indikator. Variabel efektivitas program terdiri dari enam indikator yang 
meliputi indikator input, proses dan output dengan masing - masing indikator tersebut memiliki dua butir pernyataan. Variabel kesejahteraan terbentuk atas enam indikator yang meliputi dampak pelaksanaan program terhadap kehidupan masyarakat di bidang kesehatan, sosial, dan ekonomi. Berdasarkan tabel tersebut dapat diketahui bahwa seluruh indikator yang digunakan memiliki nilai MSA diatas 0,5 yang memiliki arti bahwa model yang digunakan layak untuk digunakan untuk analisis lebih lanjut.

Tabel 4.

Nilai MSA masing - masing Indikator Variabel Penelitian

\begin{tabular}{|c|c|c|c|}
\hline No & Variabel & Indikator & Nilai MSA \\
\hline \multirow[t]{4}{*}{1} & Peran Petugas KB (X2) & $\mathrm{X} 2.1$ & 0,715 \\
\hline & & $\mathrm{X} 2.2$ & 0,545 \\
\hline & & $\mathrm{X} 2.3$ & 0,548 \\
\hline & & $\mathrm{X} 2.4$ & 0,754 \\
\hline \multirow[t]{6}{*}{2} & Efektivitas Program Kampung KB (Y1) & Y1.1 & 0,536 \\
\hline & & $\mathrm{Y} 1.2$ & 0,784 \\
\hline & & Y1.3 & 0,785 \\
\hline & & Y1.4 & 0,663 \\
\hline & & Y1.5 & 0,586 \\
\hline & & Y1.6 & 0,582 \\
\hline \multirow[t]{6}{*}{3} & Kesejahteraan Keluarga (Y2) & Y2.1 & 0,567 \\
\hline & & $\mathrm{Y} 2.2$ & 0,571 \\
\hline & & Y2.3 & 0,918 \\
\hline & & Y2.4 & 0,792 \\
\hline & & $\mathrm{Y} 2.5$ & 0,745 \\
\hline & & Y2.6 & 0,660 \\
\hline
\end{tabular}

Sumber: Data diolah, 2019

Selanjutnya dilakukan perhitungan efektivitas Program Kampung KB seperti yang terlihat pada tabel 5 sebagai berikut. 
Tabel 5.

Perhitungan Efektivitas Program Kampung KB di Kota Denpasar

\begin{tabular}{|c|c|c|c|c|}
\hline Indikator & Target & Realisasi & Persen & $\begin{array}{l}\text { Kriteria } \\
\text { Efektivitas }\end{array}$ \\
\hline \multicolumn{5}{|l|}{ Input } \\
\hline 1) Sosialisasi kegiatan & 5 & 2.47 & 49.4 & Tidak efektif \\
\hline 2) Sarana dan prasarana kegiatan & 5 & 3.02 & 60.4 & Cukup efektif \\
\hline \multicolumn{5}{|l|}{ Proses } \\
\hline 1) Pelaksanaan kegiatan & 5 & 2.69 & 53.8 & Tidak efektif \\
\hline 2) Pelayanan masyarakat & 5 & 2.38 & 47.6 & Tidak efektif \\
\hline \multicolumn{5}{|l|}{ Output } \\
\hline 1) Peningkatan keterampilan & 5 & 2.51 & 50.2 & Tidak efektif \\
\hline 2) Peningkatan hubungan sosial & 5 & 2.43 & 48.6 & Tidak efektif \\
\hline Rata - rata & 5 & 2.58 & 51.67 & Tidak efektif \\
\hline
\end{tabular}

Berdasarkan perhitungan indikator input, proses dan output pada Tabel 5 dapat diketahui bahwa koefisien tingkat efektivitas program Kampung KB di Kota Denpasar adalah sebesar 51,67 persen dan tergolong tidak efektif dalam kriteria penilaian efektivitas program tergolong dalam kategori tidak efektif. Dengan demikian berdasarkan hasil perhitungan tingkat efektivitas, pelaksanaan program Kampung KB di Kota Denpasar adalah tidak efektif.

Uji kelayakan model atau yang dikenal dengan uji $\mathrm{F}$ (uji simultan) adalah tahapan awal untuk mengidentifikasi model regresi yang diestimasi layak atau tidak. Hasil uji dikatakan layak berarti model yang diestimasi tepat digunakna untuk menjelaskan pengaruh variabel bebas terhadap variabel terikat. Kriteria pengujian ini adalah One Way Anova dengan membandingkan signifikansi tabel ANOVA. Suatu model dikatakan layak uji jika nilai signifikansinya kurang dari 0,05. Pada penelitian ini dilakukan dua uji kelayakan model. Hasil uji kelayakan model struktur 1 pada penelitian ini disajikan pada Tabel 6 . 
Tabel 6.

Hasil Uji Kelayakan Model Struktur 1

\begin{tabular}{|c|c|c|c|c|c|c|}
\hline \multirow{2}{*}{\multicolumn{2}{|c|}{ Model }} & \multicolumn{2}{|c|}{$\begin{array}{l}\text { Unstandardized } \\
\text { Coefficients }\end{array}$} & \multirow{2}{*}{$\begin{array}{c}\text { Standardized } \\
\text { Coefficients } \\
\text { Beta }\end{array}$} & \multirow[t]{2}{*}{$\mathbf{t}$} & \multirow[t]{2}{*}{ Sig. } \\
\hline & & B & Std. Error & & & \\
\hline \multirow{3}{*}{1} & (Constant) & $-1,934$ & ,385 & & $-5,026$ & ,000 \\
\hline & Pendidikan &, 191 & 037 & ,440 & 5,134 & 000 \\
\hline & Peran Petugas & 420 & 086 & 420 & 4,907 & ,000 \\
\hline \\
\hline \multicolumn{7}{|c|}{$\mathrm{R}^{2}=0,514$} \\
\hline \multicolumn{7}{|c|}{$F=41,168$} \\
\hline \multicolumn{7}{|c|}{$\mathrm{F}$ sig $=0,000$} \\
\hline
\end{tabular}

Sumber: Data diolah, 2019

Berdasarkan hasil Tabel 6 maka persamaan dari struktur 1 adalah sebagai berikut.

$$
\mathrm{Y}_{1}=0,440 \mathrm{X}_{1}+0,420 \mathrm{X}_{2}+\mathrm{e}_{1}
$$

Hasil uji kelayakan model struktur 2 pada penelitian ini disajikan pada Tabel 7 sebagai berikut.

Tabel 7.

Hasil Uji Kelayakan Model Struktur 2

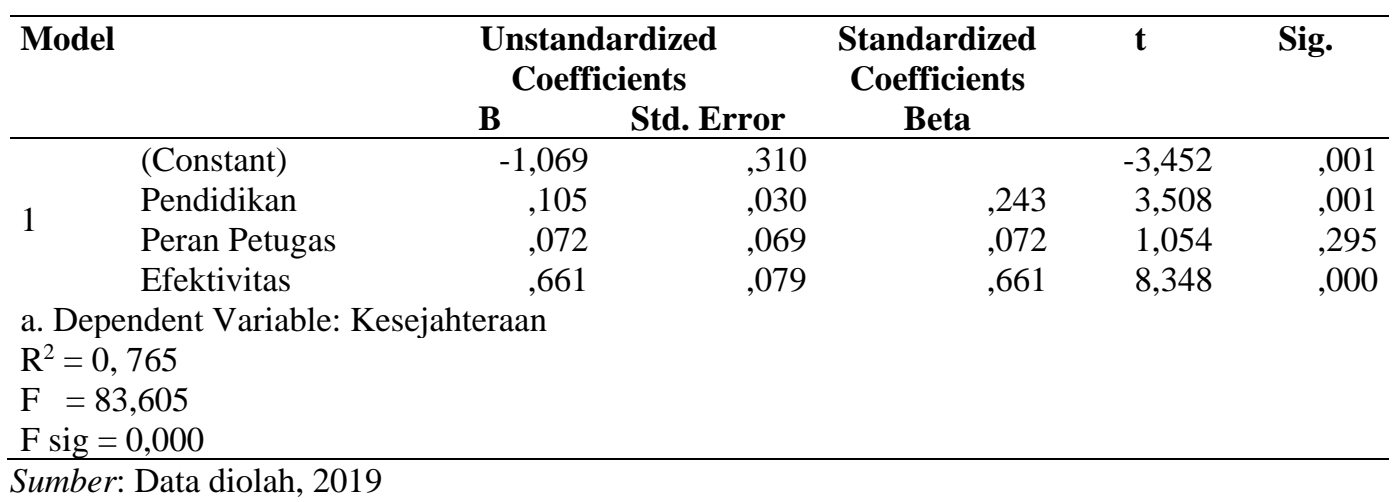

Berdasarkan hasil Tabel 8 maka persamaan dari struktur 2 adalah sebagai berikut.

$$
\mathrm{Y}_{2}=0,243 \mathrm{X}_{1}+0,072 \mathrm{X}_{2}+0,661 \mathrm{Y}_{1}+\mathrm{e}_{2}
$$


Untuk mengetahui nilai $\mathrm{e}_{1}$ yang menunjukan jumlah variasi efektivitas program Kampung KB yang tidak dijelaskan oleh variabel pendidikan istri dan peran Petugas KB dapat dihitung dengan rumus sebagai berikut.

$$
\begin{aligned}
\mathrm{e}_{1} & =\sqrt{1-R_{1}^{2}} \\
& =\sqrt{1-0,514} \\
& =0,697
\end{aligned}
$$

Untuk mengetahui nilai e2 yang menunjukkan variasi kesejahteraan keluarga yang tidak dijelaskan oleh variabel pendidikan istri, peran petugas $\mathrm{KB}$ dan efektivitas program Kampung $\mathrm{KB}$ dapat dihitung dengan rumus sebagai berikut.

$$
\begin{aligned}
\mathrm{e}_{2} & =\sqrt{1-R_{2}^{2}} \\
& =\sqrt{1-0,765} \\
& =0,488
\end{aligned}
$$

Untuk memeriksa validitas model, terdapat indikator untuk melakukan pemeriksaan yaitu koefisien determinasi total. Adapun hasil pemeriksaan validitas model penelitian ini adalah sebagai berikut.

$$
\begin{aligned}
R_{m}^{2} & =1-e_{1}^{2} \cdot e_{2}^{2} \\
& =1-(0,697)^{2}(0,488)^{2} \\
& =0,884
\end{aligned}
$$

Berdasarkan hasil perhitungan koefisien determinasi total, diperoleh nilai keragaman data yang dapat dijelaskan oleh model yakni sebesar 0,884. Hasil terebut menunjukkan bahwa 88,4 persen variasi kesejahteraan keluarga dipengaruhi oleh model yang dibentuk variabel pendidikan istri, peran petugas 
KB dan efektivitas program Kampung KB. Sisanya sebesar 11,6 persen dipengaruhi oleh variabel lain diluar model yang dibentuk.

Berdasarkan Tabel 8 dapat diketahui nilai pengaruh langsung pendidikan istri terhadap efektivitas program Kampung KB adalah sebesar 0,440. Pengaruh langsung peran petugas KB terhadap efektivitas program Kampung KB sebesar 0,420 dan pengaruh langsung efektivitas program Kampung KB terhadap kesejahteraan keluarga sebesar 0,661. Pengaruh langsung pendidikan istri terhadap kesejahteraan keluarga sebesar 0,243. Pengaruh peran petugas KB terhadap kesejahteraan keluarga sebesar 0,072. Pengaruh tidak langsung pendidikan istri terhadap kesejahteraan keluarga melalui efektivitas program Kampung KB adalah sebesar 0,291. Nilai pengaruh tidak langsung peran petugas KB terhadap kesejahteraan keluarga melalui efektivitas program Kampung KB sebesar 0,278 .

Tabel 8.

Hasil Pengaruh Langsung, Pengaruh Tidak Langsung dan Pengaruh Total Antar Variabel

\begin{tabular}{|c|c|c|c|}
\hline \multirow{2}{*}{ Hubungan Variabel } & \multicolumn{2}{|c|}{ Pengaruh } & \multirow{2}{*}{ Total } \\
\hline & Langsung & Tidak Langsung & \\
\hline $\mathrm{X}_{1 \rightarrow \mathrm{Y}_{1}}$ & 0,440 & - & 0,440 \\
\hline $\mathrm{X}_{1} \rightarrow \mathrm{Y}_{2}$ & 0,243 & 0,291 & 0,534 \\
\hline $\mathrm{X}_{2} \rightarrow \mathrm{Y}_{1}$ & 0,420 & - & 0,420 \\
\hline $\mathrm{X}_{2} \rightarrow \mathrm{Y}_{2}$ & 0,072 & 0,278 & 0,350 \\
\hline $\mathrm{Y}_{1 \rightarrow \mathrm{Y}_{2}}$ & 0,661 & - & 0,661 \\
\hline
\end{tabular}

Sumber: Data diolah, 2019

Hasil uji analisis jalur yang telah dilakukan dapat digambarkan diagram analisis jalur sebagai berikut. 


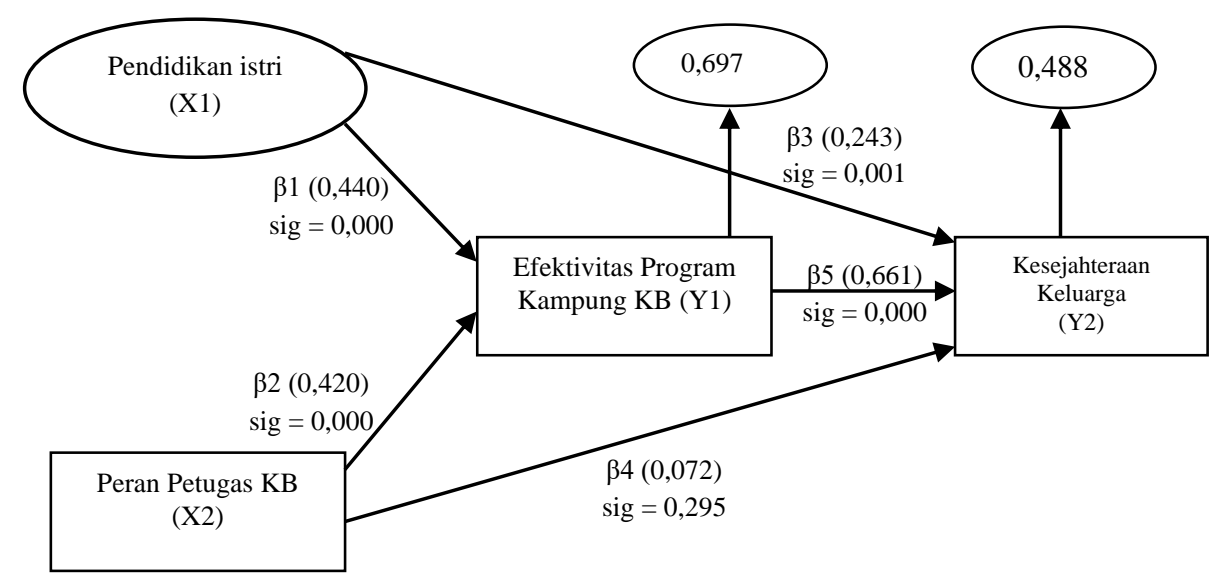

Gambar 1. Diagram Hasil Analisis Jalur Penelitian

Pengaruh tidak langsung pendidikan istri terhadap kesejahteraan keluarga melalui efektivitas program Kampung KB dapat dihitung dengan uji z. Jika z hitung $\leq$ 1,96 maka $\mathrm{H}_{0}$ diterima yang berarti efektivitas program Kampung $\mathrm{KB}$ bukan variabel intervening. Jika $\mathrm{z}$ hitung $>1,96$ maka $\mathrm{H}_{0}$ ditolak yang berarti efektivitas program Kampung KB merupakan variabel intervening.

$$
\begin{aligned}
\mathrm{S}_{\mathrm{b} 1 \mathrm{~b} 5} & =\sqrt{\beta 5^{2} S_{\beta 1}^{2}+\beta 1^{2} S_{\beta 5}^{2}} \\
& =\sqrt{(0,661)^{2}(0,037)^{2}+(0,191)^{2}(0,079)^{2}} \\
& =0,0287 \\
\mathrm{Z} & =\frac{\beta 1 \beta 5}{S \beta 1 \beta 5} \\
& =\frac{(0,191)(0,661)}{0,0287} \\
& =4,40
\end{aligned}
$$

Keterangan :

$\beta_{1} \quad=$ Koefisien regresi pengaruh variabel $\mathrm{X}_{1}$ terhadap $\mathrm{Y}_{1}$

$\beta_{5} \quad=$ Koefisien regresi pengaruh variabel $Y_{1}$ terhadap $Y_{2}$

$\mathrm{S} \beta_{1}=$ Standar error koefisien regresi variabel $\mathrm{X}_{1}$ terhadap $\mathrm{Y}_{1}$

$\mathrm{S} \beta_{5}=$ Standar error koefisien regresi variabel $\mathrm{Y}_{1}$ terhadap $\mathrm{Y}_{2}$ 
Berdasarkan hasil $\mathrm{z}$ hitung yaitu sebesar 4,40 > 1,96 maka $\mathrm{H}_{0}$ ditolak dan $\mathrm{H}_{1}$ diterima. Artinya pendidikan istri berpengaruh secara tidak langsung terhadap kesejahteraan keluarga melalui efektivitas program Kampung KB.

Pengaruh tidak langsung peran petugas KB terhadap kesejahteraan keluarga melalui efektivitas program Kampung KB dapat dihitung dengan uji z.Jika z hitung $\leq 1,96$ maka $\mathrm{H}_{0}$ diterima yang berarti efektivitas program Kampung $\mathrm{KB}$ bukan variabel intervening. Jika $\mathrm{z}$ hitung $>1,96$ maka $\mathrm{H}_{0}$ ditolak yang berarti efektivitas program Kampung KB merupakan variabel intervening.

$$
\begin{aligned}
\mathrm{S} \beta_{2} \beta_{5} & =\sqrt{\beta 5^{2} S_{\beta 2}^{2}+\beta 2^{2} S_{\beta 5}^{2}} \\
& =\sqrt{(0,661)^{2}(0,086)^{2}+(0,420)^{2}(0,079)^{2}} \\
& =0,0658 \\
Z & =\frac{\beta 2 \beta 5}{S \beta 2 \beta 5} \\
& =\frac{(0,420)(0,661)}{0,0658} \\
& =4,22
\end{aligned}
$$

Keterangan :

$\beta_{2} \quad=$ Koefisien regresi pengaruh variabel $\mathrm{X}_{2}$ terhadap $\mathrm{Y}_{1}$

$\beta_{5} \quad=$ Koefisien regresi pengaruh variabel $\mathrm{Y}_{1}$ terhadap $\mathrm{Y}_{2}$

$\mathbf{S}_{\mathbf{2}}=$ Standar error koefisien regresi variabel $\mathrm{X}_{2}$ terhadap $\mathrm{Y}_{1}$

$\mathrm{S} \beta_{5}=$ Standar error koefisien regresi variabel $\mathrm{Y}_{1}$ terhadap $\mathrm{Y}_{2}$

Berdasarkan hasil z hitung yaitu sebesar 4,22 > 1,96 maka $\mathrm{H}_{0}$ ditolak dan $\mathrm{H}_{1}$ diterima. Artinya peran petugas $\mathrm{KB}$ berpengaruh secara tidak langsung terhadap kesejahteraan keluarga melalui efektivitas program Kampung KB.

Berdasarkan hasil penelitian yang telah dilakukan, terdapat implikasi yang dihasilkan dari penelitian ini. Hasil yang diperoleh dari penelitian ini adalah pendidikan istri berpengaruh secara positif dan signifikan terhadap efektivitas 
program Kampung KB yang berarti semakin tinggi pendidikan istri, maka akan berdampak pada semakin efektifnya pelaksanaan program Kampung KB. Selanjutnya peran petugas $\mathrm{KB}$ juga berpengaruh positif dan signifikan terhadap efektivitas program Kampung KB yang mengindikasikan semakin aktif petugas KB maka pelaksanaan program Kampung KB akan semakin efektif.

Hasil penelitian ini juga menemukan bahwa pendidikan istri dan efektivitas program Kampung KB berpengaruh positif dan signifikan terhadap kesejahteraan keluarga di Kota Denpasar, sementara peran petugas KB tidak berpengaruh secara signifikan terhadap kesejahteraan keluarga miskin di Kota Denpasar. Hal tersebut menunjukkan bahwa peran petugas $\mathrm{KB}$ tidak berpengaruh terhadap kesejahteraan keluarga jika tidak mampu meningkatkan efektivitas program Kampung KB. Pada penelitian ini, efektivitas program Kampung $\mathrm{KB}$ berperan penting dalam meningkatkan kesejahteraan keluarga miskin di Kota Denpasar. Semakin efektif pelaksanaan program Kampung KB maka akan berdampak terhadap meningkatnya kesejahteraan keluarga miskin di Kota Denpasar. Sementara itu efektivitas program Kampung KB ini sendiri dipengaruhi oleh pendidikan istri dan peran petugas KB. Pendidikan istri menentukan tingkat pemahaman istri terhadap pelaksanaan kegiatan program ini dan semakin aktif petugas $\mathrm{KB}$ dalam melakukan tugas dan fungsinya maka akan berdampak pada semakin efektifnya pelaksanaan program. 


\section{SIMPULAN DAN SARAN}

Pelaksanaan program Kampung KB di Kota Denpasar belum efektif. Pendidikan istri dan peran petugas $\mathrm{KB}$ mempunyai pengaruh positif dan signifikan terhadap efektivitas program Kampung KB di Kota Denpasar. Dengan kata lain apabila pendidikan istri tinggi dan peran petugas $\mathrm{KB}$ meningkat maka pelaksanaan program Kampung KB di Kota Denpasar akan semakin efektif. Pendidikan istri berpengaruh positif dan signifikan terhadap kesejahteraan keluarga miskin, sementara peran petugas $\mathrm{KB}$ tidak signifikan pengaruhnya terhadap kesejahteraan keluarga miskin di Kota Denpasar. Efektivitas program Kampung KB berdampak positif dan signifikan terhadap kesejahteraan keluarga miskin di Kota Denpasar. Dengan kata lain semakin efektif pelaksnaaan program Kampung KB, maka kesejahteraan keluarga miskin di Kota Denpasar akan meningkat. Pendidikan istri dan peran petugas $\mathrm{KB}$ memiliki pengaruh tidak langsung terhadap kesejahteraan keluarga miskin di Kota Denpasar, atau dengan kata lain efektivitas program Kampung KB merupakan variabel yang mengintervening pendidikan istri dan peran petugas $\mathrm{KB}$ terhadap kesejahteraan keluarga miskin di Kota Denpasar.

Berdasarkan hasil penelitian ini diharapkan seluruh tim Kelompok Kerja Kampung KB dan petugas KB diharapkan dapat menjalankan tugas dan fungsinya dengan lebih optimal demi mensukseskan program Kampung KB. Dengan demikian pelaksanaan program ini akan lebih efektif. Berdasarkan hasil penelitian ini diharapkan kepada perangkat desa, pokja Kampung KB dan seluruh pemangku kepentingan agar memperbanyak kegiatan pelatihan, pendampingan maupun 
sosialisasi yang bertujuan untuk meningkatkan pengetahuan dan keterampilan masyarakat khususnya para istri dari keluarga pra-sejahtera dan keluarga KS-I. Melalui hasil penelitian ini diharapkan petugas KB lebih aktif dalam menjalankan tugasnya yang tidak hanya mencakup bidang $\mathrm{KB}$ tetapi juga ikut terlibat dalam semua kegiatan yang dapat mendukung program ini.

\section{REFERENSI}

Afniyanty. 2016. Kinerja Petugas Lapangan Keluarga Berencana (PLKB) Di Desa Pakawa Kecamatan Pasangkayu Kabupaten Mamuju Utara. Jurnal Katalogis. Vol 4 No 4.

Ardiyani, Dian. 2017. Konsep Pendidikan Perempuan Siti Wadilah. Jurnal Tajdida. Vol 15 No 1.

Badan Koordinasi Keluarga Berencana Nasional. 2009. Hubungan Program Keluarga Berencana Nasional dengan Kesejahteraan Keluarga. Jakarta : BKKBN.

----. 2017 Buku Pegangan Kader BKB dan Orang Tua Tentang Penanaman dan Penerapan Nilai Karakter Melalui 8 Fungsi Keluarga. Jakarta: BKKBN.

----. 2018. Materi Profil Penyuluh KB dan Petugas Lapangan KB Tahun 2017. Jakarta : BKKBN.

Badan Pusat Statistik. 2018. Jumlah Penduduk Miskin Menurut Provinsi. Jakarta : Indonesia.

Badan Pusat Statistik. 2018. Jumlah Penduduk Miskin Menurut Kabupaten/Kota. Denpasar: BPS Bali.

Budhi, Made Kembar Sri. 2013. Analisis Faktor-faktor Yang Berpengaruh Terhadap Pengentasan Kemiskinan Di Bali: Analisis FEM Data Panel. Jurnal Ekonomi Kuantitatif Terapan. Vol. 06, No. 02.

Fan, Shenggen, Connie Chan-Kang and Anit Mukherjee. 2005. Rural and Urban Dynamic and Poverty : Evidence from China and India. International Food Policy Research Institute.

Heryendi, Wycliffe Timotius dan Anak Agung Istri Ngurah Marhaeni. 2013. Efektivitas Program Usaha Peningkatan Pendapatan Keluarga Sejahtera (UPPKS) di Kecamatan Denpasar Barat. Jurnal Ekonomi Kuantitatif Terapan. Vol. 6 No. 2. 
Hukom, Alexandra. 2014. Hubungan Ketenagakerjaan dan Perubahan Struktur Ekonomi Terhadap Kesejahteraan Masyarakat. Jurnal Ekonomi Kuantitatif Terapan. Vol. 07, No. 02.

Hidayat AA. 2004. Pengantar Imu Keperawatan Anak I. Direktorat Jenderal Pendidikan Tinggi: Jakarta.

Kurniawan, Ukik Kusuma, Hadi Pratomo dan Adang Bachtiar. 2010. Kinerja Penyuluhan Keluarga Berencana di Indonesia: Pedoman Pengujian Efektivitas Kinerja pada Era Desentralisasi. Jurnal Kesehatan Masyarakat Nasional. Vol 5 No. $1: 3-8$.

Maipita, Indra. 2014. Memahanmi dan Mengukur Kemiskinan, Cetakan I. Yogyakarta: Penerbit Absolute Media.

Margareni, Ni Putu Ayu Purnama, I Ketut Djayastra, I.G.W. Murjana Yasa. 2016. Faktor - faktor yang Mempengaruhi Kemiskinan di Provinsi Bali. Jurnal Piramida. Vol. XII No. 1 : 101 - 110. ISSN : 1907-3275

McCulloch, Neil. 2008. 'Rice Prices and Poverty in Indonesia'. Bulletin of Indonesian Economic Studies. 44 (1): 45-64.

Pertiwi, Prita Putri Prima dan Akif Khilmiyah. 2016. Hubungan Tingkat Pendidikan Istri Dengan Pengambilan Keputusan Gugat Cerai Pada Perceraian Kdrt Di Pengadilan Agama Bantul Yogyakarta. Jurnal Ibu dan Anak. Vol 1 No 2.

Puspitawati, H. 2012. Gender dan Keluarga: Konsep dan Realita di Indonesia. PT. IPB Press : Bogor.

Riza, Hartoyo dan Istiqlaliyah Muflikhati. 2014. Kesejahteraan Keluarga Peserta dan Bukan Peserta Program Gerakan Perempuan Untuk Optimalisasi Pekarangan (GPOP). Jurnal Ilmu Keluarga dan Konsumen. Vol. 7 No. 1. ISSN : $1907-6037$.

Seran, Sirilius. 2017. Hubungan Antara Pendidikan, Pengangguran dan Pertumbuhan Ekonomi Dengan Kemiskinan. Jurnal Kuantitatif Ekonomi Terapan. Vol. 10, No. 01.

Suandi, Yuslidar, Sudirman Suma, dan Yusma Damayanti. 2014. Hubungan Karakteristik Kependudukan Dengan Kesejahteraan Keluarga di Provinsi Jambi. Jurnal Piramida. Vol. X No. 2 : 71 - 77. ISSN : 1907-3275.

Subagio, Bambang, Agus Darjanto, Andi Irawan, Cecep Winata, Darda Daraba, Fr.Harjanto, Luki Karunia, Suparmin, Theodora M Katiandagho, Anita Esfandiari, Sus Derthi Widhyari, Wiwin Winarsih, Adawiah, Afra D.N. Makalew, Sukarman, Hikmad Lukman. 2001. Kemiskinan di Indonesia dalam Perspektif Ekonomi: Sebuah Kajian Permodelan. Makalah Falsafah Sains Program Pascasarjana, IPB. 
Sunariani, Ni Nyoman, Made Sukarsa, Made Kembar Sri Budhi, AAIN Marhaeni. 2014. Kontribusi Pelaksanaan Ritual Hindu Terhadap Kesempatan Kerja dan Kesejahteraan Masyarakat di Kabupaten Badung Provinsi Bali (Studi Kasus Mlaspas dan Ngenteg Linggih di Pura Pasek Preteka Desa Abiansemal). Jurnal Ekonomi Kuantitatif Terapan.Vol. 07, No. 02.

Todaro, Michael P. 2000. Pembangunan Ekonomi di Dunia Ketiga, Edisi Ketujuh, Jakarta : Erlangga.

Uppun, Paulus. 2016. Dampak Pelaksanakan Kebijakan Otonimu Daerah Terhadap Pelayanan KB dan Pengendalian Kelahiran di Provinsi Sulawesi Selatan. Jurnal Piramida. Vol. XII No. 2. ISSN : 1907-3275

Yusuf, Dicky, dkk. 2018. Kinerja Petugas Lapangan Keluarga Berencana. Jurnal Universitas Muhammadiyah Palu. Tersedia di https://jurnal.unismuhpalu.ac.id/index.php/JSM/article/download/173/127 diakses pada 15 November 2018 pukul 13.47.

Yusuf, Arief Anshory dan Andy Sumner. 2015. Growth, Poverty, and Inequality under Jokowi. Bulletin International Economy Studies. Vol. 51 No. 3. ISSN: 0007-4918

Zuhriyah, Aminatuz, Sofwan Indarjo dan Bambang Budi Raharjo. 2017. Kampung Keluarga Berencana Dalam Peningkatan Efektivitas Program Keluarga Berencana. Higeia Journal Of Public Health Research And Development. Vol. 1 No. 4. 